\title{
Influence of Phosvitin and Calcium Gluconate Concentration on Permeation and Intestinal Absorption of Calcium Ions
}

\author{
Barbara Dolińska $\cdot$ Katarzyna Lopata • \\ Agnieszka Mikulska • Lucyna Leszczyńska • \\ Florian Ryszka
}

Received: 14 September 2011 / Accepted: 5 December 2011 / Published online: 10 January 2012

(C) The Author(s) 2012. This article is published with open access at Springerlink.com

\begin{abstract}
The effect of egg yolk phosvitin on the permeation and absorption of calcium was investigated in vitro in relation to calcium gluconate concentration. Obtained results indicate that phosvitin significantly reduces the intestinal calcium absorption from 1 and $10 \mathrm{mM}$ of calcium gluconate solution. It is associated with the formation of the complex of $\mathrm{Ca}$ (II) ions with phosvitin. The process of calcium permeation increases under phosvitin influence when calcium gluconate concentrations rise up to $10 \mathrm{mM}$. At a higher concentration of calcium gluconate $(20 \mathrm{mM})$, no effect of phosvitin was seen on permeation of calcium ions.
\end{abstract}

Keywords Phosvitin - Calcium gluconate - Permeability Intestinal absorption $\cdot$ In vitro

\section{Introduction}

Calcium is an essential element involved in electrolytic balance and regulatory mechanisms in the organism $[1,2]$. Insufficient calcium intake is a recognized risk of osteoporosis. Calcium absorption ranges from 10-75\%, depending on the age and physiological status of individuals.

Increasing the effectiveness of calcium absorption by means of substances that positively influence its absorption are active areas of interest. Some of the substances that have been found

B. Dolińska $(\bowtie) \cdot$ A. Mikulska $\cdot$ L. Leszczyńska $\cdot$ F. Ryszka

Biochefa Pharmaceutical Research and Production Plant,

Kasztanowa 3,

41-205 Sosnowiec, Poland

e-mail: b.dolinska@biochefa.pl

B. Dolińska $\cdot$ K. Łopata

Department of Applied Pharmacy, Medical University of Silesia,

Sosnowiec, Poland to increase the intestinal calcium absorption from the gastrointestinal tract include vitamin D, magnesium, casein, inulin and other resistant sugars, and some amino acids [3].

The same effect could be demonstrated by phosvitin phosphopeptides [3, 4]. Phosvitin is the most active peptide from egg yolk and comprises about $7 \%$ of yolk dry matter [5]. In egg yolk, phosvitin naturally forms calcium aggregates created by phosphocalcic bridges [6].

Phosvitin is an acidic protein rich in phosphate groups bound mainly by serine. In acidic solutions with low ionic strength, phosvitin has a good potential for metal chelating. It is able to form complexes with divalent ions such as $\mathrm{Ca}^{2+}$, $\mathrm{Mg}^{2+}, \mathrm{Co}^{2+}, \mathrm{Mn}^{2+}$, and with $\mathrm{Fe}^{3+}[6,7]$.

It has been suggested that phosvitin phosphate anions enhance calcium absorption and bioavailability. In some studies, phosvitin phosphopeptides were found to have a high calcium-binding ability. Moreover, these phosphopeptides inhibit formation of insoluble calcium salts and improve $\mathrm{Ca}$ (II) absorption in the small intestine. Phosvitin peptides added to diets at a concentration of $0.125-0.5 \%$ $(1.25-5.0 \mathrm{mg} / \mathrm{g})$ significantly increase $\mathrm{Ca}$ absorption and accumulation in bones [4, 8, 9].

In this study we determined the influence of phosvitin on permeation of calcium ions in relation to three different concentrations of calcium gluconate from a simulated stomach environment to an acceptor medium that imitated the ileum section of the GI tract.

\section{Materials and Methods}

Substances

Phosvitin from egg yolk - phosphoglycoprotein $(M=34 \mathrm{kDa})$ containing $8-10 \%(w / w)$ phosphorus was purchased from 
Sigma-Aldrich Chemie, Buchs. Calcium gluconate $\mathrm{Ca}$ $\left(\mathrm{C}_{6} \mathrm{H}_{11} \mathrm{O}_{7}\right)_{2} \times \mathrm{H}_{2} \mathrm{O}(M=448.4 \mathrm{~g} / \mathrm{mol}, 8 \%$ calcium content $)$ was purchased from Pharma Cosmetics, Poland. All substances were analytically pure and compatible with quality standards and certificates.

\section{Small Intestine}

The study was carried out on 15 specimens of small intestine that were collected from 6-month-old pigs weighing $100 \pm 2 \mathrm{~kg}$. The intestine specimens weighed on average $290 \pm 10 \mathrm{mg}$. Once removed from the carcass and dissected, the intestines were washed with $0.9 \% \mathrm{NaCl}$ solution to an absorbance value with an extinction coefficient $\varepsilon<0.02$ at $278 \mathrm{~nm}$, and then quickly frozen at $-20^{\circ} \mathrm{C}$ until needed for the experiments [13].

\section{Physiological Fluids}

Physiological fluids mimicking the natural conditions of the stomach and ileum: artificial gastric juice at $\mathrm{pH} 1.3$ and artificial intestinal fluid at $\mathrm{pH} 7.5$, respectively $[11,12]$.

\section{Research Model}

The study was carried out in a standard Franz diffusion cell with two 2-ml identical chambers fitted with input and output channels [14]. One side acted as the donor (D) chamber and the other as the acceptor (A). A disk cut from the small intestine tissue was used to separate compartments D and A, which were kept at the same level as required in the "side-by-side" method. Chamber D (simulating stomach) was filled with $2 \mathrm{ml}$ of artificial gastric juice $(\mathrm{pH}$ 1.3) in which calcium gluconate at different concentrations (40, 400, or $800 \mathrm{mg} / \mathrm{l}$ ) were dissolved (control groups) or $20 \mu \mathrm{g} / 1$ of phosvitin were additionally added. Chamber A (ileum) was filled with $2 \mathrm{ml}$ of the artificial intestinal fluid $(\mathrm{pH} \mathrm{7.5).} \mathrm{The}$ lowest concentration was used as model of a calciumdeficient state.

The experiment was carried out with a stable chamber oscillation at a rate of $50 \mathrm{rpm}$. After $0,0.25,0.50,0.75,1.0$, 2.0, 3.0, 4.0, and $5.0 \mathrm{~h}$, the entire content of chamber A was collected and replaced with $2.0 \mathrm{ml}$ of fresh fluid. At the end of each experiment, the content of both chambers was collected and the amount of $\mathrm{Ca}(\mathrm{II})$ that permeated through the intestine tissue was calculated from the difference $D-A$, where $D$ is the total amount of $\mathrm{Ca}$ (II) in milligrams per liter that remains in chamber $\mathrm{D}$ and $A$ is the total amount of $\mathrm{Ca}$ (II), also in milligrams per liter that permeated through the intestine after $5 \mathrm{~h}$.
Calcium Analysis

A validated spectrophotometric method was used for the determination of calcium (II) ions using a "Calcium OCPC Kit" from Pointe Scientific [15]. The absorbance was measured at $\lambda=570 \mathrm{~nm}$ in 1.0 -cm glass cuvettes with a UVVIS "Marcel-Media" spectrophotometer (France). The photometric accuracy of the spectrophotometer was $\pm 0.005 \mathrm{~A}$. The empirical regression equation $y=1.06 x+0.41$ was used to establish the relationship between $\left[\mathrm{Ca}^{2+}\right]$ and the absorbance. The significance of the equation was $R^{2}=0.994$.

\section{Statistical Analysis}

The data are given as means \pm standard deviation, with $n=$ 10 for all groups. The permeability and absorption process of $\mathrm{Ca}(\mathrm{II})$ ions depends on the concentration of calcium gluconate in the control groups and were used to compare the results of runs where phosvitin was also added. The Student's $t$ test was used to establish statistical significance, set at $p<0.05$. The software packages Excel (Microsoft) and Statistic for Windows 5.1 (StatSoft Inc.) were used for all calculations.

\section{Results and Discussion}

Calcium homeostasis maintains the $\mathrm{Ca}(\mathrm{II})$ concentration within physiological limits in the organism. The balance between permeation and intestinal calcium absorption is one of the $\mathrm{Ca}(\mathrm{II})$ homeostasis mechanisms. The amount of absorbed calcium depends on many factors that may stimulate or inhibit the absorption process $[1-3,16]$. Some researchers claim that calcium is a threshold nutrient, meaning that the relationship between $\mathrm{Ca}$ intake and its level in the body occurs just between a certain range and higher intakes do not result in higher calcium accumulation in bones $[10,17]$.

After $5 \mathrm{~h}$ in the calcium-deficient model $(1 \mathrm{mM}$ calcium gluconate), $11 \mathrm{mg} / 1$ (27\%) Ca(II) was lost from D but

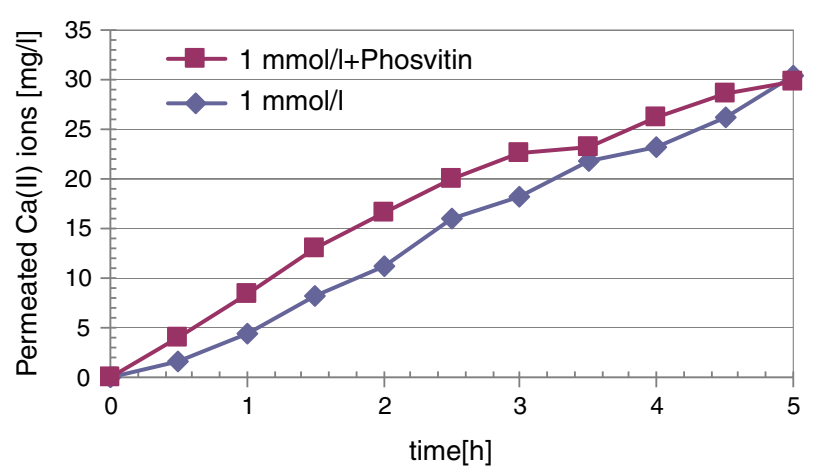

Fig. 1 Influence of phosvitin on permeation of $\mathrm{Ca}$ (II) ions at $1 \mathrm{mM}$ calcium gluconate concentration during $5 \mathrm{~h}$ 
Table 1 Influence of phosvitin and calcium gluconate concentration on permeation and absorption of $\mathrm{Ca}(\mathrm{II})$ ions through small intestine after $5 \mathrm{~h}$

\begin{tabular}{|c|c|c|c|c|c|c|c|c|c|}
\hline \multirow{2}{*}{\multicolumn{2}{|c|}{ Concentration of calcium gluconate }} & \multicolumn{4}{|c|}{ Donor $(D)$} & \multirow{2}{*}{\multicolumn{2}{|c|}{ Acceptor $(A) \mathrm{Ca}(\mathrm{II})$ permeated }} & \multirow{2}{*}{\multicolumn{2}{|c|}{$\mathrm{Ca}(\mathrm{II})$ absorbed $(\mathrm{D}-\mathrm{A})$}} \\
\hline & & \multicolumn{2}{|c|}{$\mathrm{Ca}(\mathrm{II})$ loss } & \multicolumn{2}{|c|}{ Residual Ca(II) } & & & & \\
\hline $\mathrm{mM}$ & $\mathrm{mg} / 1$ & $(\mathrm{mg} / \mathrm{l})$ & $(\%)$ & $(\mathrm{mg} / \mathrm{l})$ & $(\%)$ & $(\mathrm{mg} / \mathrm{l})$ & $(\%)$ & $(\mathrm{mg} / \mathrm{l})$ & $(\%)$ \\
\hline 1 & 40.0 & 10.5 & 26.2 & $29.5 \pm 2.2$ & 73.9 & $27.9 \pm 1.2$ & 69.8 & $-17.4 \pm 1.5$ & -43.6 \\
\hline $1+$ phosvitin & 40.0 & 19.6 & 49.1 & $20.4 \pm 3.1$ & 50.9 & $\uparrow 27.4 \pm 1.9$ & 68.5 & $\downarrow-7.8 \pm 0.9 *$ & -19.5 \\
\hline 10 & 400 & 327.6 & 81.9 & $72.4 \pm 3.8$ & 18.1 & $30.0 \pm 1.6$ & 7.5 & $297.6 \pm 1.9$ & 74.4 \\
\hline $10+$ phosvitin & 400 & 251.6 & 62.9 & $148.4 \pm 3.2 *$ & 37.1 & $\uparrow 54.4 \pm 0.9 *$ & 13.6 & $\downarrow 197.2 \pm 3.5^{*}$ & 49.3 \\
\hline 20 & 800 & 445.4 & 55.7 & $354.6 \pm 2.7$ & 44.3 & $83.8 \pm 0.9$ & 10.5 & $361.6 \pm 3.3$ & 45.2 \\
\hline $20+$ phosvitin & 800 & 428.0 & 53.5 & $372.0 \pm 4.2$ & 46.5 & $\uparrow 72.0 \pm 5.2$ & 9.0 & $\uparrow 356.0 \pm 2.9$ & 44.5 \\
\hline
\end{tabular}

${ }^{*} p<0.05$, statistically significant in relation to control groups at the same gluconate concentration

$28 \mathrm{mg} / \mathrm{l}(70 \%)$ reached chamber A. The $17 \mathrm{mg} / \mathrm{l}(44 \%)$ difference must have been supplied by the tissue separating these chambers. When phosvitin is also added, the loss of $\mathrm{Ca}$ (II) from D increased to $20 \mathrm{mg} / \mathrm{l}(50 \%)$, while $27 \mathrm{mg} / \mathrm{l}(68 \%)$ passed on to A, suggesting that phosvitin inhibited the mobilization from the intestine tissue, supplying only $20 \%$ of Ca(II) ions in hypocalcemia. The influence of phosvitin on permeation of $\mathrm{Ca}$ (II) from $1 \mathrm{mM}$ calcium gluconate solution is shown in Fig. 1.

Phosvitin did not change the amount of $\mathrm{Ca}$ (II) passing through but caused a twofold decrease of its absorption. The permeation and absorption data in relation to calcium gluconate concentration are given in Table 1.

Increasing the concentration of $\mathrm{Ca}$ (II) ions to $10 \mathrm{mM}$, almost the same amount of $\mathrm{Ca}(\mathrm{II})$ ions $(30 \mathrm{mg} / \mathrm{l}, 75 \%)$ permeated through small intestine while $298 \mathrm{mg} / \mathrm{l}$ were absorbed by the small intestine tissue. This process is significantly changed by phosvitin, which causes a twofold increase of $\mathrm{Ca}$ (II) permeation, Fig. 2.

At an even higher concentration of calcium gluconate (20 mM), $84 \mathrm{mg} / \mathrm{l}(11 \%)$ of $\mathrm{Ca}(\mathrm{II})$ ions passed from $\mathrm{D}$ to A and $362 \mathrm{mg} / 1$ were absorbed. Addition of phosvitin did not change $\mathrm{Ca}$ (II) permeation or absorption at this concentration. The influence of phosvitin on the dynamics of $\mathrm{Ca}$ (II)

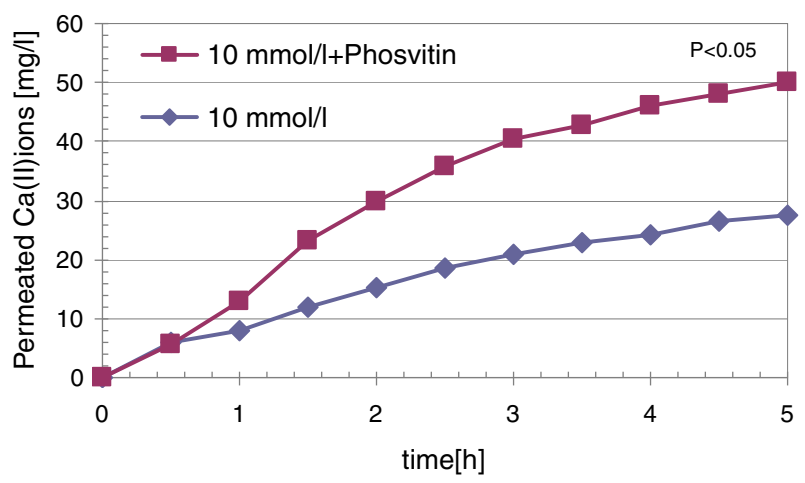

Fig. 2 Influence of phosvitin on permeation of $\mathrm{Ca}(\mathrm{II})$ ions at $10 \mathrm{mM}$ calcium gluconate concentration during $5 \mathrm{~h}$ permeation from $20 \mathrm{mM}$ calcium gluconate solution is given in Fig. 3.

Recent findings indicate that egg yolk phosvitin added to diet significantly enhances $\mathrm{Ca}$ absorption and accumulation in bones of rats [4]. Phosvitin contains $300 \mathrm{ppm}$ of bound $\mathrm{Ca}$ (II) and in its presence over $400 \mathrm{ppm}$ out of $1,000 \mathrm{ppm}$ added protein is soluble, compared to $150 \mathrm{ppm}$ without phosvitin [4].

The results from this study suggest that egg yolk phosvitin decreases the $\mathrm{Ca}$ absorption at calcium-deficient condition. At $10 \mathrm{mM}$ calcium gluconate phosvitin significantly increases $\mathrm{Ca}(\mathrm{II})$ permeation $(p<0.05)$. These results are in agreement with previous reports about the decrease of absorption of calcium, magnesium, and iron caused by phosvitin [18].

\section{Conclusions}

The obtained results suggest that in a calcium deficiency state, phosvitin might inhibit mobilization of calcium from the small intestine. Egg yolk phosvitin significantly decreases $\mathrm{Ca}$ (II) absorption from 1 and $10 \mathrm{mM}$ Ca gluconate

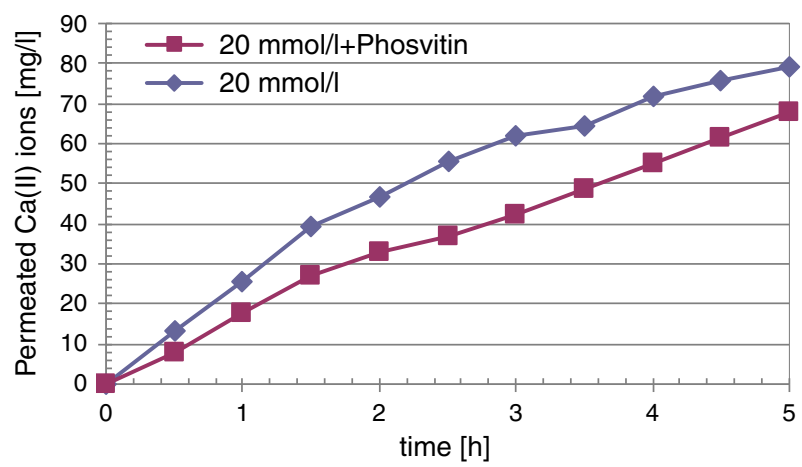

Fig. 3 Influence of phosvitin on $\mathrm{Ca}(\mathrm{II})$ ions permeation at $20 \mathrm{mM}$ calcium gluconate concentration during $5 \mathrm{~h}$ 
solutions and substantially increases its permeation from the $10 \mathrm{mmol} / \mathrm{l} \mathrm{Ca}$ gluconate solution.

Acknowledgments The research was conducted with funds for a project co-financed by the European Regional Development Foundation as a part of the Operating Program of Innovative Economy No. UDA-POIG.01.03.1-00-133/08-00: "Innovative technologies of the production of bio-preparations on the basis of new generation of eggs" in the years 2009-2011.

Open Access This article is distributed under the terms of the Creative Commons Attribution Noncommercial License which permits any noncommercial use, distribution, and reproduction in any medium, provided the original author(s) and source are credited.

\section{References}

1. Straub DA (2007) Calcium supplementation in clinical practice: a review of forms, doses, and indications. Nutr Clin Pract 3:286-296

2. Bronner F (2009) Recent developments in intestinal calcium absorption. Nutr Rev 67:109-113

3. Dolińska B, Mikulska A, Ryszka F (2008) Promotory wchłaniania wapnia. [Factors enhancing calcium's absorption]. Ann Acad Med Siles 1:89-96

4. Choi J, Jung Ch (2005) Effectives of phosvitin peptides on enhancing bioavailability of calcium and its accumulation in bones. Food Chem 93:577-583

5. Dolińska B, Wożniak D, Ryszka F (2009) Białka żółtka jaja kurzego, właściwości i zastosowanie. Farm Przegl Nauk 6:1922

6. Belhomme C, David-Briand E, Guerin-Dubiard C (2008) Phosvitin-calcium aggregation and organization at the air-water interface. Colloids and Surfaces B: Biointerfaces 63:12-20
7. Catellani O, Guerin-Dubiard C, David-Briand E (2004) Influence of physicochemical conditions and technological treatments on the iron binding capacity of egg yolk phosvitin. Food Chem 85:569-577

8. Jiang Bo, Mine J (2000) Preparation of novel functional oligophosphopeptides from hen egg yolk phosvitin. J Agric Food Chem 48:90-994

9. Jiang Bo, Mine J (2001) Phosphopeptides derived from hen egg yolk phosvitin: effect of molecular size on the calcium-binding properties. Biosci Biotechnol Biochem 65:1187-1190

10. Dolińska B, Mikulska A, Ryszka F (2008) Skuteczność preparatów wapnia $\mathrm{w}$ profilaktyce jego niedoborów [Calcium preparation effectivess in prevention of acalcerosis]. Farm Przegl Nauk 7-8:5-8

11. Dolińska B, Mikulska A, Caban A, Cieślik A, Ryszka F (2011) A model for calcium permeation into small intestine. Biol Trace Elem Res 140:95-102

12. Dolińska B, Mikulska A, Ostróżka-Cieślik A, Ryszka F (2011) The influence of condition on permeation of $\mathrm{Ca}(\mathrm{II})$ ions from solutions of selected calcium's salts through model membrane. Biol Trace Elem Res 142:456-464

13. Toledo-Pereyra LH, Lopez-Neblina F, Toledo A (2010) Organ freezing. In: Toledo-Pereyra LH (ed) Organ preservation for transplantation third edition.(/books/iu/id/2258/). Landes Bioscience, Austin

14. Franz TJ (1975) Percutaneus absorption and the relevance of in vitro data. J Invest Derm 64:190-195

15. Nowatzke W, Woolf E (2007) Best practices during bioanalytical method validation for the characterization of assay reagents and the evaluation of analyte stability in assay standards, quality controls, and study samples. AAPS J 9:E117-E122

16. Hoenderop J, Nilius B, Bindels R (2005) Calcium absorption across epithelia. Physiol Rev 85:373-422

17. Heaney RP (2002) The importance of calcium intake for lifelong skeletal health. Calcif Tissue Int 70:70-73

18. Ishikawa SI, Tamaki S, Arihara K (2007) Egg yolk protein and egg yolk phosvitin inhibit calcium, magnesium, and iron absorptions in rats. J Food Sci 6:412-419 